\title{
TOWARDS AN EFFICIENT APPROACH FOR IDENTIFICATION AND SELECTION OF STAKEHOLDER ENGAGEMENT STRATEGIES: A CASE STUDY
}

\section{Mohammad Khalilzadeh', Omid Kebriyaii ${ }^{2}$, Jonas Šaparauskas ${ }^{3}$, Natalija Lepkova ${ }^{4}$}

1 Pontificia Universidad Católica del Perú, Centrum Católica Graduate Business School, Peru, ORCID: 0000-00022373-8505, khalilzadeh@pucp.edu.pe (corresponding author);

2 Iran University of Science and Technology, Department of Industrial Engineering, Iran, ORCID: 0000-0002-4988-9600, omidkebriyaii71@gmail.com;

3 Vilnius Gediminas Technical University, Faculty of Civil Engineering, Department of Construction Management and Real Estate, Lithuania, ORCID: 0000-0003-3685-7754, jonas.saparauskas@vilniustech.It;

4 Vilnius Gediminas Technical University, Faculty of Civil Engineering, Department of Construction Management and Real Estate, Lithuania, ORCID: 0000-0002-9760-1747, natalija.lepkova@vilniustech.It.

\begin{abstract}
The goals and objectives of a project as well as the needs, requirements and expectations of the project stakeholders may contradict or non-fulfillment of them may have different detrimental and negative consequences for the project. Therefore, project stakeholders should be effectively managed, but it is not possible to satisfy all project stakeholders and meet all of their expectations and requirements. As a result, project team must strike a balance between the project goals and objectives and the needs, requirements and expectations of the project stakeholders in order to complete the project successfully. Despite highlighting the significant importance of project stakeholder management, there exists a notable gap in exerting an effective decision support system to adopt stakeholder engagement strategies particularly in oil and gas construction projects. This study proposes a comprehensive framework for the identification, prioritization and selection of the stakeholder engagement strategies in one of the large size oil and gas construction projects in Iran. In this paper, a hybrid method which is the combination of the SWOT (strengths, weakness, opportunities and threat) analysis and fuzzy Delphi method is first exploited for identifying the appropriate stakeholder engagement strategies. Subsequently, fuzzy SWARA (Step-wise Weight Assessment Ratio Analysis) is employed to weight the crucial criteria, and finally, fuzzy WASPAS (Weighted Aggregated Sum Product Assessment) is utilized to prioritize the identified stakeholder engagement strategies. This research contributes to the body of knowledge on project stakeholder management by presenting a novel framework for identifying, ranking and selecting the suitable strategies for effective stakeholder engagement considering one of the largest oil and gas construction projects in the country. The value of this study is in applicability of the proposed methodology for project managers and practitioners in other oil and gas construction projects.
\end{abstract}

Keywords: Stakeholder engagement, Strategy selection, SWOT analysis, Fuzzy Delphi method, Fuzzy SWARA-WASPAS, Oil and gas project.

JEL Classification: L69, C61, C63.

APA Style Citation: Khalilzadeh, M., Kebriyaii, O., Šaparauskas, J., \& Lepkova, N. (2021). Towards an Efficient Approach for Identification and Selection of Stakeholder Engagement Strategies: A Case Study. E\&M Economics and Management, 24(4), 56-71. https://doi. org/10.15240/tul/001/2021-4-004 


\section{Introduction}

Freeman (1984) describes stakeholders as "those groups who can affect or is affected by the achievement of the firm's objectives". "Each stakeholder will either expect or demand to be part of all critical decisions on the project" (Kerzner, 2009). The stakeholder engagement is the most substantial matter in any project (Abidin, 2010). Stakeholders are defined as legal entities or individuals who have stakes in a project or are able to affect project execution (Olander, 2005). McGrath and Whitty (2017) define stakeholder as "an entity with a stake (interest) in the subject activity". Stakeholders can significantly influence on project outputs. At each project phase, the number and type of stakeholders may vary and have different interests that should be effectively met (Oppong et al., 2017). These different interests may conflict with each other and certainly make it even more difficult to determine stakeholder engagement strategies. It is not practically possible to make all project stakeholders satisfied.

A balance between the stakeholders' interests and the project objectives should be considered to resolve the existing conflicts (Bahadorestani et al., 2020). Stakeholder management literally assists project managers with selecting strategies to maximize the value of project for its stakeholders (Cleland, 1999). Stakeholder management is dealing with making stakeholders satisfied through engaging them and resolving their conflicts. Stakeholder engagement is inevitable in project success (Eyiah-Botwe et al., 2016). Li et al. (2013) describe stakeholder satisfaction as 'the fulfilment of stakeholders' pre-project expectations in the actual performance which are measurable at different project stages". Most stakeholders generally attempt to affect project implementation. Stakeholder satisfaction is met by achieving their particular goals and objectives such as cost, time and quality (Davis, 2016).

In oil and gas construction projects, stakeholder management is of utmost importance since a great number of these construction projects is mega-projects that have various stakeholders (Merrow, 2012). Ineffective stakeholder management in megaprojects leads to numerous problems and detrimental impacts (Kumaraswamy et al., 2017). Once the most significant stakeholders' interests are specified for project success, several stakeholder engagement strategies should be acquired to prevent their negative impacts on project performance (Aarseth et al., 2017). Improper stakeholder engagement strategies can jeopardize project implementation (Loosemore, 2010). Defining appropriate stakeholder engagement strategies can restrain wrong decision-making that leads to failure to achieve project goals.

There is a significant gap in providing and ranking stakeholder engagement strategies, especially for oil and gas projects. Therefore, this paper attempts to fill this gap with presenting a framework to identify, rank and select appropriate strategies for stakeholder engagement in one of the most complex and largest oil and gas construction projects in Iran.

\section{Theoretical Background 1.1 Project Success}

Different definitions have been proposed for project success, such as attaining schedule, budget, and performance criteria, since stakeholders may have various descriptions for project success according to their needs and expectations (Pinto \& Slevin, 1987). For instance, meeting project schedule is obviously fundamental for project success based on four groups of stakeholders' viewpoints comprising project sponsor, project manager, customer, and end user (Davis, 2017). Locatelli et al. (2014) investigated complex projects considering time, cost and quality factors as critical success factors and highlighted stakeholder management for boosting project performance. Stakeholder engagement plays an important role in project success. Therefore, it is vital for project managers to recognize and analyze stakeholders' concerns to achieve project success (Atkin \& Skitmore, 2008).

\subsection{Stakeholder Engagement}

Stakeholder management deals with the commitment for fulfilling project stakeholders' interests (Post et al., 2002; Bowie \& Werhane, 2004). Mitchell et al. (1997) examined the typology and interests of stakeholders. Cleland (1999) highlighted the important role of effective stakeholder management in preventing several conflicts and yielding project success. Projects are carried out within limited period of time, however their consequences may last for a long time which makes the stakeholder management 
more crucial (Eskerod et al., 2015). Project stakeholder should be identified and recognized in order to effectively manage them (Eskerod \& Larsen, 2017). Stakeholder engagement, "which is often simplified as an act of corporate social responsibility" (Collinge, 2020), is a preliminary facet of stakeholder management (APM, 2012). Stakeholder engagement is typically defined as the innumerable means of stakeholders' involvement during the project life cycle related to information collection, knowledge sharing, decision-making and problem solving (Mysore et al., 2019). "Project stakeholder management includes the processes required to identify the people, groups, or organizations that could impact or be impacted by the project, to analyze stakeholder expectations and their impact on the project, and to develop appropriate management strategies for effectively engaging stakeholders in project decisions and execution" (PMI, 2017). Collinge (2020) investigated the distinctive features of stakeholder engagement in construction sector. Stakeholder engagement may be considered as a strategic procedure for promoting innovation and reducing conflict (Yu \& Leung, 2018).

Yang et al. (2010) distinguished the key success factors for stakeholder management in construction projects and revealed that managing conflicts is one of the top-ranked factors. In addition, Li et al. (2011) studied the key success factors of managing the stakeholders of construction projects. Eskerod and Huemann (2013) probed the concepts of stakeholder management in project management standards such as PMBOK, PRINCE2, and ICB. Davis (2014) collected the critical success factors of project including time, cost and quality and the most important stakeholder groups such as sponsor, project manager and customer. Davis (2016) investigated the key success factors of various groups of stakeholders. Most studies have highlighted the project managers' viewpoints about project success and neglected other stakeholders. Davis (2014) stated that there is no consensus on project success factors between project management team, project team and other stakeholders. Mok et al. (2017) distinguished the most substantial stakeholders in cultural building projects (CBPs) and their most principal concerns. Erkul et al. (2019) examined the stakeholder engagement and concluded that project success heavily relies on stakeholders' satisfaction, which is the outcome of appropriate interactions with stakeholders. Mysore et al. (2019) studied some detrimental factors and situations such as dysfunctional conflicts that have negative impacts on engaging stakeholders. Each stakeholder has contradictory needs, interests, and expectations which cause several conflicts among them. The cognitive situations may be positive or negative based on stakeholders' interests. For example, the situation of 'conflict' or 'pressure' can be positive for a group of stakeholders such as customers, and on the other hand, the other group of stakeholders such as suppliers can realize the same situations in a worthless manner. Yu et al. (2019) developed a mathematical model to trade off different stakeholders' interests and diminish the conflicts between various project stakeholders' groups. Nguyen et al. (2019) revealed that stakeholders as a set of organizations or individuals can pursue different strategies to negatively affect the project implementation. Bahadorestani et al. (2020) proposed a framework for managing stakeholder with ranking conflict sources through the judgement of project management team and stakeholders.

Eldanfour et al. (2014) compared the diverse impact of stakeholders in developed and developing countries' oil and gas sectors. Chinweze (2015) studied the stakeholder engagement in oil and gas sectors in Nigeria. De Vita et al. (2016) investigated the stakeholders of oil and gas sectors in Nigeria to attain a better knowledge about the scope of stakeholders' interactions and how such interactions are in line with favorable conditions for national development. Mbelwa (2018) identified governments, local communities, employees and shareholders as the main stakeholders.

\subsection{The SWOT Analysis in Oil and Gas Industry}

Tavana et al. (2011) assessed different direct ways of oil and gas export from the Caspian Sea to the world markets. They applied the Delphi method as well as the SWOT analysis to assess the alternative strategies for choosing the ways. Xingang et al. (2013) exploited the SWOT analysis for developing the Chinese shale gas status. Four types of productivity development strategies for this industry were formulated based on the SWOT analysis. Khan (2018) used the SWOT analysis to evaluate the 
environment of CNG industry. Nine strategies were considered by using the SWOT analysis to understand the growth rate of Iranian CNG market. Subsequently, a fuzzy goal programming approach was used to evaluate those strategies. Azubuike et al. (2018) identified the main policies and legal issues for shale gas development in Algeria. The internal key factors (weaknesses and strengths) and external key factors (opportunities and threats) were taken into consideration. Hajizadeh (2019) took advantage of the machine learning technology in the oil and gas industry. The SWOT analysis was applied to manage the strategies for technology enablement.

\subsection{The Fuzzy Delphi Technique in Oil and Gas Industry}

Kimiagari et al. (2015) used the fuzzy Delphi technique to examine their proposed conceptual framework linking the strategic coalitions and their facilitators for expanding the knowledge capabilities of upstream oil and gas industry. Kazemi et al. (2018) applied the fuzzy Delphi technique to determine the delay factors of oil and gas construction projects in Iran. Barghi and Shadrokh sikari (2020) exploited the fuzzy Delphi method and expert judgement to distinguish principal risk factors of oil exploration and exploitation phases. Dahooie et al. (2018) evoked a primary criteria list for supplier selection in oil and gas well-drilling projects, and used the expert judgement as well as the fuzzy Delphi method to gain the criteria list.

\subsection{The Fuzzy SWARA and WASPAS Methods in Oil and Gas Industry}

Yazdi et al. (2020) first applied the Delphi technique for screening the main factors for oil project selection. Then, they used a combination of BWM and WASPAS methods to select oil projects in Iran. Ayyildiz and Taskin Gumus (2020) exploited a fuzzy AHP-WASPAS method to choose the best location for petrol station.

According to the literature review, there are not common success factors among numerous groups of project stakeholders and the majority of the studies identified the critical success factors based on project managers' viewpoints. Some situations can be positive for various groups of stakeholder and other stakeholder groups can realize the analogous situations in a worthless manner. Not paying enough attention to several stakeholder groups can trigger different problems and cost overruns in projects and negatively affect project outcomes. In addition, appropriate stakeholder engagement positively affects stakeholders' satisfaction, higher level of stakeholder satisfaction, higher likelihood of project success. Hence, investigating stakeholder engagement in megaprojects, particularly oil and gas construction projects is of paramount importance.

For this purpose, developing a framework including the SWOT analysis is necessary for identifying the strengths and weaknesses as two internal key factors and opportunities and threats as two external key factors. In addition, proposing a decision-making method such as the fuzzy Delphi method is beneficial for determining proper stakeholder engagement strategies. Moreover, fuzzy SWARA is employed for weighting the defined criteria considering decision-makers' priorities. Furthermore, fuzzy WASPAS is exploited for prioritizing the identified stakeholder engagement strategies. Despite numerous studies on stakeholder engagement, there has been no research on determination and selection of appropriate stakeholder engagement strategies, particularly in oil and gas construction megaprojects. In addition, no study on project stakeholder management has been found that used the fuzzy SWARA-WASPAS method. Since the number of pairwise comparisons in the SWARA method has decreased and this method removes inconsistency, experts are able to comment more freely. WASPAS method is also a reliable multi-criteria decision-making method and is much more accurate than other methods (Agarwal et al., 2020). This study attempts to fill in this gap to a large extent.

The contribution of this study is two-fold:

- Exploiting a fuzzy hybrid method with the combination of the SWOT analysis and fuzzy Delphi method for determining the appropriate stakeholder engagement strategies together with employing SWARAWASPAS technique to weight the criteria and prioritize the stakeholder engagement strategies;

- Implementing the proposed method for the first time in one of the largest and most complex oil and gas construction projects in Iran as a real case study. 


\section{Methodology}

In this study, the appropriate strategies for stakeholder engagement were determined by using the SWOT analysis method and screened by using fuzzy Delphi method. Subsequently, the criteria were weighted by using the SWARA method taking decision-makers' preferences into account, and finally, the strategies were prioritized through the fuzzy SWARA-WASPAS method.

\subsection{The SWOT Analysis Method}

Strategic management deal with the effective decisions to assist project teams with achieving their long-term goals (Burgelman et al., 2008). Surrounding environment may affect strategic decisions. The success of an organization or project depends on external and internal factors. The SWOT analysis is used to identify key internal (organizational) factors as well as external (environmental) factors in order to achieve strategic goals. Internal factors include strengths (S) and weaknesses (W). External factors include opportunities $(\mathrm{O})$ and threats (T). Internal and external factors are ranked to attain the desirable strategies. The output of the SWOT analysis is a combination of two internal and external factors (S, W, O and T) (Khatir \& Akbarzadeh, 2019).

\subsection{Fuzzy Delphi Method}

The Delphi method uses verbal expressions to measure viewpoints. Verbal expressions have some limitations in fully reflecting the respondent's opinions. For instance, the expression 'high' may differ between two individuals. Therefore, a definite number cannot be used to quantify both different viewpoints. Fuzzy sets theory has been widely applied to quantify linguistic and ambiguous human explanations. Kaufmann and Gupta (1988) exploited the triangular fuzzy numbers $(l, m, u)$ for the Delphi method. Since then, many studies have been conducted on the fuzzy Delphi technique. The triangular fuzzy numbers for the five-point Likert scale is expressed in terms of the importance of the indices (Tab. 1) (Habibi et al., 2015).

Then, the expert judgments are converted into fuzzy numbers. Next, the experts' viewpoints are accumulated according to formula (1):

$$
F_{A V E}=\frac{\sum l}{n}, \frac{\sum m}{n}, \frac{\sum u}{n}
$$

Subsequently, the obtained triangular fuzzy numbers are defuzzified by using the modified center of area method based on formula (2) (Tzeng \& Teng, 1993):

$$
D F_{i j}=\frac{\left[\left(u_{i j}-l_{i j}\right)+\left(m_{i j}-l_{i j}\right)\right]}{3}+l_{i j}
$$

\subsection{Fuzzy SWARA Method}

SWARA method was first proposed by Kersuliene et al. (2010) to estimate the weights of criteria taking decision-makers' preferences into consideration. The process of identifying the importance weights of criteria using fuzzy SWARA is the same as the one used by Mavi et al. (2017).

\subsection{Fuzzy WASPAS Method}

WASPAS method was originally introduced by Zavadskas et al. (2012). The process of prioritizing the stakeholder engagement strategies is similar to the fuzzy WASPAS method which was proposed by Turskis et al. (2015).

Fig. 1 depicts the steps of the proposed methodology.

\section{Application of Proposed Framework}

In this section, the framework was implemented on one of the Iranian oil and gas construction megaprojects. The stakeholders were recognized through document analysis, historical information and lessons learned from past similar projects as well as expert judgement. The required data were collected using questionnaires distributed to the 23

Tab. 1: Triangular fuzzy numbers for five-point Likert scale (Habibi et al., 2015)

\begin{tabular}{c|c|c|c|c} 
Not important & Slightly important & $\begin{array}{c}\text { Moderately } \\
\text { important }\end{array}$ & Important & Very important \\
\hline$(0 ; 0 ; 0.25)$ & $(0 ; 0.25 ; 0.5)$ & $(0.25 ; 0.5 ; 0.75)$ & $(0.5 ; 0.75 ; 1)$ & $(0.75 ; 1 ; 1)$ \\
\hline
\end{tabular}




\section{Fig. 1: The steps of the proposed methodology}

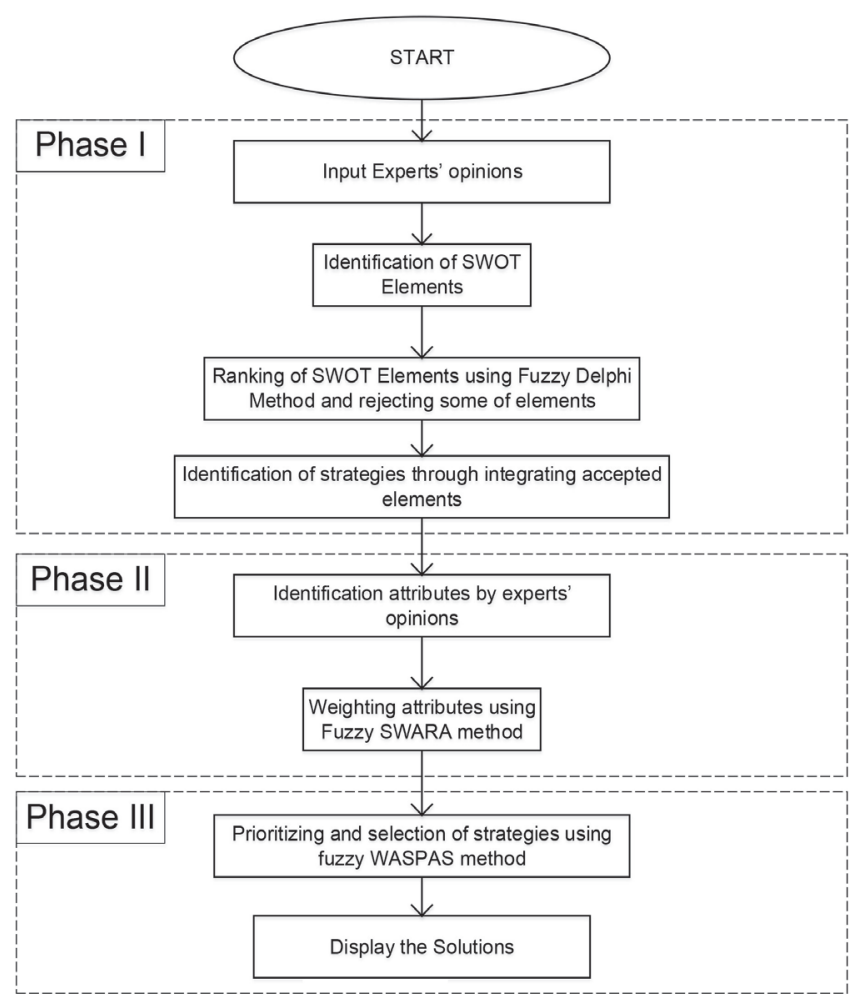

Source: own

PMP-certified experts with more than ten years of practical experience in the oil and gas construction projects to distinguish strengths, weaknesses, opportunities, and threats, and strategies. The SWOT analysis was carried step by step; the elements were defined first, and then they were assessed. In this paper, the factors of SWOT analysis were identified and evaluated in order to determine stakeholder engagement strategies. Triangular fuzzy numbers were exploited to deal with the vagueness of the linguistic and verbal variables. Subsequently, the key factors and strategies were ranked by using the fuzzy Delphi method. The Kendall coefficient with the value greater than or equal 0.7 was considered as the stopping index for the procedure of the Delphi method (Silvério et al., 2019). In addition, since the fuzzy SWARA method consists of $n-1$ number of pairwise comparisons, there is no need to check the incompatibility rate (Agarwal et al., 2020).

\subsection{Results}

Tab. 2 represents the obtained results of ranking internal factors. It should be noted that the threshold value for selection is 0.7 (Habibi et al., 2015).

As shown in Tab. 2, the top-ranked weaknesses are as follows: 'Low ability to attract new projects', 'Poor managers' trust in project team' and 'Low trust in document management systems'. The most significant strengths factors are obtained as follows: 'Organizational Agility', 'Good relationships with employers' and 'Appropriate financial resources'. 


\section{Tab. 2: Ranking the internal factors}

\begin{tabular}{l|c|c|c|c|c}
\multicolumn{1}{c|}{ Internal factors } & Type & Code & Fuzzy weight & $\begin{array}{c}\text { Defuzzifi- } \\
\text { cation }\end{array}$ & $\begin{array}{c}\text { Select/ } \\
\text { reject }\end{array}$ \\
\hline $\begin{array}{l}\text { Irregular payment of bills by the } \\
\text { employer }\end{array}$ & Weakness & W1 & $(0.37 ; 0.62 ; 0.84)$ & 0.608 & Reject \\
\hline Improper organizational structure & Weakness & W2 & $(0.34 ; 0.59 ; 0.79)$ & 0.574 & Reject \\
\hline Use of multi-skills resources & Weakness & W3 & $(0.43 ; 0.68 ; 0.9)$ & 0.667 & Reject \\
\hline Low ability to attract new projects & Weakness & W4 & $(0.56 ; 0.81 ; 0.96)$ & 0.775 & Select \\
\hline Restrictions of business areas & Weakness & W5 & $(0.38 ; 0.63 ; 0.84)$ & 0.618 & Reject \\
\hline $\begin{array}{l}\text { Inadequate use of key human } \\
\text { resources in specialized jobs }\end{array}$ & Weakness & W6 & $(0.41 ; 0.66 ; 0.85)$ & 0.642 & Reject \\
\hline $\begin{array}{l}\text { Low trust in document management } \\
\text { systems }\end{array}$ & Weakness & W7 & $(0.57 ; 0.82 ; 0.97)$ & 0.789 & Select \\
\hline Poor managers' trust in project team & Weakness & W8 & $(0.54 ; 0.79 ; 0.94)$ & 0.760 & Select \\
\hline Organizational agility & Strength & S1 & $(0.56 ; 0.81 ; 0.96)$ & 0.775 & Select \\
\hline Availability of proficient resources & Strength & S2 & $(0.38 ; 0.63 ; 0.84)$ & 0.618 & Reject \\
\hline $\begin{array}{l}\text { Access to various ports in the } \\
\text { Persian Gulf }\end{array}$ & Strength & S3 & $(0.51 ; 0.68 ; 0.91)$ & 0.672 & Reject \\
\hline Optimal project management system & Strength & S4 & $(0.37 ; 0.62 ; 0.78)$ & 0.588 & Reject \\
\hline $\begin{array}{l}\text { Utilization of the state-of-the-art } \\
\text { technical knowledge }\end{array}$ & Strength & S5 & $(0.29 ; 0.54 ; 0.75)$ & 0.529 & Reject \\
\hline Availability of adequate equipment & Strength & S6 & $(0.28 ; 0.53 ; 0.75)$ & 0.520 & Reject \\
\hline $\begin{array}{l}\text { Constructive relationships and } \\
\text { cooperation with competent } \\
\text { contractors and suppliers }\end{array}$ & Strength & S7 & $(0.43 ; 0.68 ; 0.9)$ & 0.667 & Reject \\
\hline Good relationships with employers & Strength & S8 & $(0.59 ; 0.84 ; 0.99)$ & 0.804 & Select \\
\hline Appropriate financial resources & Strength & S9 & $(0.5 ; 0.69 ; 0.91)$ & 0.721 & Select \\
\hline
\end{tabular}

\section{Tab. 3: $\quad$ Ranking the external factors - Part 1}

\begin{tabular}{l|c|c|c|c|c}
\multicolumn{1}{c|}{ External factors } & Type & Code & Fuzzy weight & $\begin{array}{c}\text { Defuzzifi- } \\
\text { cation }\end{array}$ & $\begin{array}{c}\text { Select/ } \\
\text { reject }\end{array}$ \\
\hline $\begin{array}{l}\text { Increasing the exchange rates of } \\
\text { foreign currencies }\end{array}$ & Threat & T1 & $(0.53 ; 0.76 ; 0.95)$ & 0.751 & Select \\
\hline $\begin{array}{l}\text { Inadequate oil platform to continue } \\
\text { current activities }\end{array}$ & Threat & T2 & $(0.6 ; 0.85 ; 0.98)$ & 0.812 & Select \\
\hline Oil and gas sanctions & Threat & T3 & $(0.35 ; 0.59 ; 0.78)$ & 0.573 & Reject \\
\hline $\begin{array}{l}\text { Poor supply of raw materials needed } \\
\text { to accomplish activities }\end{array}$ & Threat & T4 & $(0.45 ; 0.69 ; 0.91)$ & 0.682 & Reject \\
\hline $\begin{array}{l}\text { Inadequate access to new required } \\
\text { technologies }\end{array}$ & Threat & T5 & $(0.46 ; 0.69 ; 0.86)$ & 0.667 & Reject \\
\hline \begin{tabular}{l} 
Insufficient procurement contracts \\
\hline
\end{tabular} & Threat & T6 & $(0.51 ; 0.75 ; 0.91)$ & 0.722 & Select \\
\hline
\end{tabular}




\begin{tabular}{l|c|c|c|c|c}
\multicolumn{1}{c|}{ External factors } & Type & Code & Fuzzy weight & $\begin{array}{c}\text { Defuzzifi- } \\
\text { cation }\end{array}$ & $\begin{array}{c}\text { Select/ } \\
\text { reject }\end{array}$ \\
\hline $\begin{array}{l}\text { Excessive oil and gas extraction by } \\
\text { neighboring countries }\end{array}$ & Threat & $T 7$ & $(0.61 ; 0.86 ; 0.98)$ & 0.82 & Select \\
\hline $\begin{array}{l}\text { Project execution at unreasonably } \\
\text { lower prices than the competitors }\end{array}$ & Threat & $T 8$ & $(0.29 ; 0.54 ; 0.75)$ & 0.529 & Reject \\
\hline $\begin{array}{l}\text { Employers' trust in company } \\
\text { performance }\end{array}$ & Opportunity & O1 & $(0.51 ; 0.76 ; 0.9)$ & 0.72 & Select \\
\hline $\begin{array}{l}\text { Need of increasing oil and gas } \\
\text { production }\end{array}$ & Opportunity & O2 & $(0.28 ; 0.53 ; 0.75)$ & 0.520 & Reject \\
\hline $\begin{array}{l}\text { The strategic importance of oil and } \\
\text { gas industry }\end{array}$ & Opportunity & O3 & $(0.43 ; 0.67 ; 0.89)$ & 0.661 & Reject \\
\hline $\begin{array}{l}\text { The need of using local experts } \\
\text { due to sanctions and lack of foreign } \\
\text { competent companies }\end{array}$ & Opportunity & O4 & $(0.37 ; 0.62 ; 0.78)$ & 0.588 & Reject \\
\hline $\begin{array}{l}\text { National cohesion for localization and } \\
\text { using internal power }\end{array}$ & Opportunity & O5 & $(0.54 ; 0.76 ; 0.91)$ & 0.741 & Select \\
\hline $\begin{array}{l}\text { The presence of some foreign } \\
\text { investor companies due to the } \\
\text { absence of strong competitors }\end{array}$ & Opportunity & O6 & $(0.45 ; 0.68 ; 0.87)$ & 0.677 & Reject \\
\hline $\begin{array}{l}\text { Internal knowledge-based and } \\
\text { innovation companies }\end{array}$ & Opportunity & O7 & $(0.53 ; 0.69 ; 0.91)$ & 0.725 & Select \\
\hline
\end{tabular}

Tab. 3 represents the obtained results of ranking external factors.

Together with the analysis of the internal factors (Tab. 2), the external factors analysis (Tab. 3) is substantial for the SWOT matrix. The four important strategic threats including 'increasing the exchange rates of foreign currencies', 'inadequate oil platform to continue current activities', 'insufficient procurement contracts' and 'excessive oil and gas extraction by neighboring countries' are determined. Subsequently, the three significant opportunities including 'employers' trust in company performance', 'national cohesion for localization and using internal power' and 'internal knowledge-based and innovation companies' are identified as well.

The illustration of the 15 appropriate stakeholder engagement strategies that are specified by experts is represented in Tab. 4 .

\begin{tabular}{|c|c|c|c|}
\hline Tab. 4: & $\begin{array}{l}\text { The stra } \\
\text { - Part } 1\end{array}$ & gic issues and the proposed stak & older engagement strategies \\
\hline $\begin{array}{l}\text { Strategy } \\
\text { number }\end{array}$ & Region & Question & Strategy \\
\hline Str1 & ST & $\begin{array}{l}\text { How is it possible to resolve the } \\
\text { difficulty and challenge of the improper } \\
\text { oil platform for the firm's current } \\
\text { operations with existing inadequate } \\
\text { procurement contracts by grabbing the } \\
\text { opportunities } 1,3,6 \text { and } 9 \text { ? }\end{array}$ & $\begin{array}{l}\text { Forming consortiums for exploitation } \\
\text { and extraction in cooperation } \\
\text { with neighboring countries and } \\
\text { international companies regarding the } \\
\text { expanding the empowering networks } \\
\text { and localizing technology to improve } \\
\text { stakeholder engagement }\end{array}$ \\
\hline
\end{tabular}




\begin{tabular}{|c|c|c|c|}
\hline Tab. 4: & str & ic issues and the proposed stak & Ider engagement strategies \\
\hline $\begin{array}{l}\text { Strategy } \\
\text { number }\end{array}$ & Region & Question & Strategy \\
\hline Str2 & ST & $\begin{array}{l}\text { How is it possible to gain the high } \\
\text { volume of oil and gas extraction by } \\
\text { taking advantage of the opportunities } 2 \text {, } \\
3,4 \text { and } 6 \text { despite the sanctions? }\end{array}$ & $\begin{array}{l}\text { Using the capacity of local experts } \\
\text { and supplying organizational and } \\
\text { operational optimization provisions } \\
\text { for facilitating extracting and financing } \\
\text { operations }\end{array}$ \\
\hline Str3 & ST & $\begin{array}{l}\text { How is it possible to resolve the } \\
\text { difficulty and challenge of inadequate } \\
\text { access to state-of-the-art knowledge } \\
\text { and technology as well as the difficulty } \\
\text { of providing the quality raw materials } \\
\text { required to execute activities by } \\
\text { grasping the opportunities } 2,3,4,6 \\
\text { and } 7 ?\end{array}$ & $\begin{array}{l}\text { Expanding free-trade zones to involve } \\
\text { international investors and potential } \\
\text { stakeholders at a certain level in } \\
\text { initiating, completing and developing } \\
\text { such oil and gas projects }\end{array}$ \\
\hline Str4 & SO & $\begin{array}{l}\text { How is it possible to catch the } \\
\text { opportunities such as: employers' trust } \\
\text { in the firm's efficiency and performance } \\
\text { national capabilities and localization by } \\
\text { grabbing the opportunities } 1 \text { and } 7 ?\end{array}$ & $\begin{array}{l}\text { Forming particular partnership } \\
\text { systems according to the firm's } \\
\text { requirements with special supportive } \\
\text { means for synergies between experts } \\
\text { and employers }\end{array}$ \\
\hline Str5 & SO & $\begin{array}{l}\text { How do the domestic knowledge-based } \\
\text { firms cooperate in the best possible } \\
\text { means for developing the oil and gas } \\
\text { projects considering the lack of world- } \\
\text { wide recognized firms due to sanctions by } \\
\text { grabbing the opportunities } 1,2,4 \text { and } 5 \text { ? }\end{array}$ & $\begin{array}{l}\text { Founding knowledge-based } \\
\text { organizations in oil and gas industry } \\
\text { with the social and governmental } \\
\text { assistance and support }\end{array}$ \\
\hline Str6 & SO & $\begin{array}{l}\text { How is it possible to take advantage of } \\
\text { the presence of some foreign investors } \\
\text { due to the absence of large companies } \\
\text { by grabbing the opportunities } 2,4 \text { and } 5 ?\end{array}$ & $\begin{array}{l}\text { Holding different workshops and } \\
\text { conferences about exploration and } \\
\text { exploitation topics with the help and } \\
\text { support of company and stakeholders }\end{array}$ \\
\hline Str7 & SO & $\begin{array}{l}\text { How is it possible to increase the rates } \\
\text { of production and sales according to } \\
\text { the increase of domestic consumption } \\
\text { by grabbing the opportunities } 2,4,5 \\
\text { and } 7 ?\end{array}$ & $\begin{array}{l}\text { Structuring joint oil platforms together } \\
\text { with the neighboring countries for } \\
\text { increasing the stakeholders' financial } \\
\text { shares }\end{array}$ \\
\hline Str8 & SO & $\begin{array}{l}\text { Considering the necessity of using } \\
\text { domestic skills due to the sanctions } \\
\text { and the existence of a limited number } \\
\text { of foreign firms, how is it possible to } \\
\text { use the state-of-the-art knowledge and } \\
\text { technology? }\end{array}$ & $\begin{array}{l}\text { Forming and developing the } \\
\text { national and foreign exhibitions } \\
\text { and foreign helixes for presenting } \\
\text { the development opportunities of } \\
\text { the oil and gas industry and its } \\
\text { corresponding downstream industries } \\
\text { emphasizing their geographical } \\
\text { location and economic value taking } \\
\text { advantage of potential stakeholders }\end{array}$ \\
\hline Str9 & SO & $\begin{array}{l}\text { How is it possible to use the potential } \\
\text { of having sound relationships with } \\
\text { the employers and a good project } \\
\text { management system for increasing the } \\
\text { oil and gas production? }\end{array}$ & $\begin{array}{l}\text { Presenting appropriate technical- } \\
\text { economic feasibility study plans } \\
\text { according to stakeholder engagement } \\
\text { as a comprehensive corporate action } \\
\text { plan }\end{array}$ \\
\hline
\end{tabular}




\begin{tabular}{|c|c|c|c|}
\hline Tab. 4: & $\begin{array}{l}\text { le strat } \\
\text { Part } 3\end{array}$ & ic issues and the proposed stak & Ider engagement strategies \\
\hline $\begin{array}{l}\text { Strategy } \\
\text { number }\end{array}$ & Region & Question & Strategy \\
\hline Str10 & WT & $\begin{array}{l}\text { How is it possible to solve the problem } \\
\text { of the firm's low capability to get new } \\
\text { projects and irregular payments by the } \\
\text { employers for minimizing the detrimental } \\
\text { consequences of threats } 2 \text { and } 6 ?\end{array}$ & $\begin{array}{l}\text { Acquiring information and projects } \\
\text { with the use of startups and the } \\
\text { capacity of social and NGO networks }\end{array}$ \\
\hline Str11 & WT & $\begin{array}{l}\text { Despite the managers' low trust in } \\
\text { the project teams and the document } \\
\text { management systems and improper } \\
\text { organizational structure, is it possible to } \\
\text { find a solution for minimizing the effects } \\
\text { of threats } 4,5 \text { and } 7 \text { on the projects as } \\
\text { well as stakeholders? }\end{array}$ & $\begin{array}{l}\text { Using organizational engineering } \\
\text { expertise and knowledge for structural } \\
\text { integration and conflict resolution } \\
\text { between the organization and } \\
\text { stakeholders by providing a proper } \\
\text { structural and functional model }\end{array}$ \\
\hline Str12 & WT & $\begin{array}{l}\text { Despite the restrictions of the firm's } \\
\text { practice areas and the inadequate use } \\
\text { of experts, how is it possible to reduce } \\
\text { the effects of threats } 1,3 \text { and } 8 \text { on the } \\
\text { firm's activities? }\end{array}$ & $\begin{array}{l}\text { Persuading internal investors and } \\
\text { stakeholders for participation in the } \\
\text { expansion of the national oil and gas } \\
\text { industry }\end{array}$ \\
\hline Str13 & WO & $\begin{array}{l}\text { How is it possible to use the opportunities } \\
\text { of employers' trust in the firm's performance } \\
\text { and the knowledge-basedand innovative } \\
\text { organizations for mitigating the weaknes- } \\
\text { ses of low capability of acquiring new } \\
\text { projects as well as managers' low trust in } \\
\text { the project teams? }\end{array}$ & $\begin{array}{l}\text { Establishing knowledge-based oil and } \\
\text { gas companies for attracting different } \\
\text { projects and training the needed } \\
\text { personnel }\end{array}$ \\
\hline Str14 & wo & $\begin{array}{l}\text { How is it possible to take advantage of } \\
\text { the national cohesion for highlighting } \\
\text { the localization and national power in } \\
\text { the absence of large foreign investor } \\
\text { companies to remove some present } \\
\text { restrictions? }\end{array}$ & $\begin{array}{l}\text { Establishing seasonal proper } \\
\text { exhibitions for showing the latest } \\
\text { achievements and needs of the oil } \\
\text { and gas industry by actively involving } \\
\text { stakeholders }\end{array}$ \\
\hline Str15 & WO & $\begin{array}{l}\text { How is it possible to take advantage of } \\
\text { the strategic importance of the oil and } \\
\text { gas industry and the necessity of local } \\
\text { expertise for improving the payments } \\
\text { plans, organizational structure, projects' } \\
\text { budgets and experts' skill? }\end{array}$ & $\begin{array}{l}\text { Forming an organizational network } \\
\text { of consultants with diverse expertise } \\
\text { such as technical, financial, legal } \\
\text { and engineering for organizing and } \\
\text { operational and strategic planning with } \\
\text { the cooperation of the stakeholders }\end{array}$ \\
\hline
\end{tabular}

\section{Tab. 5: The criteria}

\begin{tabular}{c|c} 
C1 & Key stakeholders' satisfaction level \\
\hline C2 & Governmental support \\
\hline C3 & Social benefits \\
\hline C4 & Operationality \\
\hline C5 & Profitability \\
\hline C6 & Risk \\
\hline
\end{tabular}




\section{Business Administration and Management}

Then, these strategies are prioritized based on the criteria considering decisionmakers' preferences. The criteria were defined by the experts, shown in Tab. 5 . The weights of the criteria and the rankings of stakeholder engagement strategies are given in Tab. 6 and Tab. 7, respectively.

As seen in Tab. 7, the top-ranked strategies are as follows: 'Establishing specific partnership systems based on company requirements with specific supportive approaches for synergies between employers and available experts', 'Utilizing the capacity of local knowledge and human resources and providing organizational and operational optimization requirements to facilitate extraction and financing operations' and 'Establishment of consortiums for exploitation and extraction with neighboring countries and international corporations based on the development of empowering networks and technology localization to enhance stakeholder engagement'.

Tab. 6:
\begin{tabular}{c|c|c|c|c|l|l|l|l|l|l|l|l} 
Criteria & \multicolumn{3}{|c|}{$\tilde{\boldsymbol{s}}_{\boldsymbol{j}}$} & \multicolumn{3}{c|}{$\tilde{\boldsymbol{k}}_{j}$} & \multicolumn{3}{|c|}{$\tilde{\boldsymbol{q}}_{j}$} & \multicolumn{3}{c}{$\tilde{\boldsymbol{w}}_{j}$} \\
\hline C1 & - & - & - & 1 & 1 & 1 & 1 & 1 & 1 & 0.313 & 0.407 & 0.596 \\
\hline C5 & 0.4 & 0.65 & 1.5 & 1.400 & 1.650 & 2.500 & 0.400 & 0.606 & 0.714 & 0.125 & 0.247 & 0.426 \\
\hline C2 & 0.29 & 0.63 & 1.5 & 1.286 & 1.633 & 2.500 & 0.160 & 0.371 & 0.555 & 0.05 & 0.151 & 0.331 \\
\hline C4 & 0.4 & 0.6 & 1.5 & 1.400 & 1.600 & 2.500 & 0.064 & 0.232 & 0.397 & 0.02 & 0.094 & 0.236 \\
\hline C3 & 0.29 & 0.47 & 0.667 & 1.286 & 1.467 & 1.667 & 0.038 & 0.158 & 0.309 & 0.012 & 0.064 & 0.184 \\
\hline C6 & 0.40 & 0.75 & 1.500 & 1.400 & 1.750 & 2.500 & 0.015 & 0.090 & 0.220 & 0.005 & 0.037 & 0.131 \\
\hline
\end{tabular}

Source: own

Note: $\tilde{s_{j}}=$ minimal, arithmetic mean and maximal value of the corresponding scores; $\tilde{k_{j}}=$ coefficient value; $\tilde{q_{j}}=$ fuzzy recalculated weights; $\widetilde{w}_{j}=$ final relative weights of criteria.

\section{Tab. 7: The ranking results of the strategies}

\begin{tabular}{c|c} 
Strategy number & Scores \\
\hline Str1 & 0.945847082 \\
\hline Str2 & 0.798428585 \\
\hline Str3 & 0.674562871 \\
\hline Str4 & 0.732096039 \\
\hline Str5 & 0.660696406 \\
\hline Str6 & 0.574436372 \\
\hline Str7 & 0.911055536 \\
\hline Str8 & 0.80287405 \\
\hline Str9 & 0.835495676 \\
\hline Str10 & 0.55524309 \\
\hline Str11 & 0.655848554 \\
\hline Str12 & 0.4302277 \\
\hline Str13 & 0.761949784 \\
\hline Str14 & 0.557159866 \\
\hline Str15 & 0.789326864 \\
\hline & \\
\hline
\end{tabular}




\section{Conclusion and Discussions}

The stakeholders are utmost important for successful project performance. Each project phase may have several stakeholders that have various conflicting needs and requirements. Hence, it is vital to adopt different strategies for effectively engaging project stakeholders to achieve project goals. This paper proposed a new methodology including the SWOT analysis and fuzzy Delphi method for determining and filtering the internal key factors (strengths and weaknesses) together with the external key factors (opportunities and threats) as well as the stakeholder engagement strategies. In addition, in this paper, fuzzy SWARA-WASPAS was employed to weight the criteria and prioritize the stakeholder engagement strategies.

\section{Contributions to the Theoretical Background}

The megaprojects' executive management should consider the significant role of stakeholders, participate them in decisionmakings (Derakhshan et al., 2019), and develop effective stakeholder engagement strategies (Erkul et al., 2019), as stakeholders can have impact on project objectives and goals (Nguyen et al., 2019). In other words, threats leading to project failure may be avoided or mitigated by successfully engaging project stakeholders (PMI, 2017). Nguyen et al. (2019) declared that stakeholder engagement plans, should influence collaboration with the governmental authorities to gain and increase their support. Effective stakeholder engagement over the entire project lifecycle can be achieved by a sound stakeholder engagement framework (Mok et al., 2015), "organizing external stakeholder engagement in inter-organizational projects" (Lehtinen \& Aaltonen, 2020).

It should be noted that conflicts of interests can negatively influence successful stakeholder engagement. There are various factors in any project that may cause conflicts and hinder project success (Ismail et al., 2018). Taking stakeholders' concerns into consideration and resolving their conflicts are important for effective stakeholder engagement (Bahadorestani et al., 2020).

This research contributes to the body of knowledge on project stakeholder engagement by presenting a comprehensive framework for identification, prioritization and selection of the appropriate strategies for effective stakeholder engagement and conflict resolution considering one of the largest oil and gas projects in the country.

\section{Managerial Implications}

Pragmatic recommendations have been presented for managerial decisions aiming at improving the present situation of interaction with stakeholders through applying the proper strategies as follows:

1 - The company should seek to establish consortiums with international companies and neighboring countries for oil and gas exploration and extraction projects to strengthen the stakeholders' cooperation.

2 - It is recommended to participate the local human resources as potential stakeholders in ongoing and future oil and gas construction projects.

3 - The company may create a platform with the support of the government for international traders, investors and potential stakeholders.

4 - The knowledge-based companies in the oil and gas industry should be supported by the government.

5 - Conferences and workshops can also form scientific relationships and improve the stakeholders' engagement level.

6 - Organizing domestic and foreign exhibitions to introduce the development opportunities of oil and gas industry by emphasizing their economic value and geographical location.

7 - Startups and the social networks may help to increase the stakeholders' collaboration.

\section{References}

Aarseth, W., Ahola, T., Aaltonen, K., Økland, A., \& Andersen, B. (2017). Project sustainability strategies: A systematic literature review. International Journal of Project Management, 35(6), 1071-1083. https://doi.org/10.1016/j. ijproman.2016.11.006

Abidin, N. Z. (2010). Investigating the awareness and application of sustainable construction concept by Malaysian developers. Habitat International, 34(4), 421-426. https:// doi.org/10.1016/j.habitatint.2009.11.011

APM. (2012). Body of Knowledge (6th ed.). Princes Risborough: Association for Project Management (APM).

Agarwal, S., Kant, R., \& Shankar, R. (2020). Evaluating solutions to overcome 
humanitarian supply chain management barriers: A hybrid fuzzy SWARA - Fuzzy WASPAS approach. International Journal of Disaster Risk Reduction, 51, 101838. https://doi.org/10.1016/j.ijdrr.2020.101838

Atkin, B., \& Skitmore, R. M. (2008). Editorial: stakeholder management in construction. Construction Management and Economics, 26(6), 549-552. https://doi. org/10.1080/01446190802142405

Ayyildiz, E., \& Taskin Gumus, A. (2020). A novel spherical fuzzy AHP-integrated spherical WASPAS methodology for petrol station location selection problem: a real case study for İstanbul. Environmental Science and Pollution Research, 27(12), 36109-36120. https://doi.org/10.1007/s11356-020-09640-0

Azubuike, S. I., Songi, O., Irowarisima, M., \& Chinda, J. K. (2018). Identifying policy and legal issues for shale gas development in Algeria: A SWOT analysis. The Extractive Industries and Society, 5(4), 469-480. https:// doi.org/10.1016/j.exis.2018.10.005

Bahadorestani, A., Naderpajouh, N., \& Sadiq, R. (2020). Planning for sustainable stakeholder engagement based on the assessment of conflicting interests in projects. Journal of Cleaner Production, 242, 118402. https://doi.org/10.1016/j.jclepro.2019.118402

Barghi, B., \& Shadrokh sikari, S. (2020). Qualitative and quantitative project risk assessment using a hybrid PMBOK model developed under uncertainty conditions. Heliyon, 6(1), e03097. https://doi.org/10.1016/j. heliyon.2019.e03097

Burgelman, R. A., Christensen, C. M., \& Wheelwright, S. C. (2008). Strategic Management of Technology and Innovation. New York, NY: McGraw-Hill Education.

Bowie, N. E., \& Werhane, P. H. (2004). Management Ethics. Malden, MA: WileyBlackwell.

Chinweze, C., Echetebu, C., \& Onyeri, I. (2015). Stakeholders engagement in the Oil and Gas Industry in Nigeria. In IAIA15 Conference Proceedings: Impact Assessment in the Digital Era, 35th Annual Conference of the International Association for Impact Assessment (pp. 1-6). Florence, Italy.

Cleland, D. I. (1999). Project Management: Strategic Design and Implementation. New York, NY: McGraw-Hill Education.

Collinge,W. (2020). StakeholderEngagement in Construction: Exploring Corporate Social
Responsibility, Ethical Behaviors, and Practices. Journal of Construction Engineering and Management, 146(3), 04020003. https://doi. org/10.1061/(ASCE)CO.1943-7862.0001769

Dahooie, J. H., Zavadskas, E. K., Abolhasani, M., Vanaki, A., \& Turskis, Z. (2018). A novel approach for evaluation of projects using an Interval-Valued Fuzzy Additive Ratio Assessment (ARAS) method: A case study of oil and gas well drilling projects. Symmetry, 10(2), 45. https://doi.org/10.3390/sym10020045

Davis, K. (2014). Different stakeholder groups and their perceptions of project success. International Journal of Project Management, 32(2), 189-201. https://doi.org/10.1016/j. ijproman.2013.02.006

Davis, K. (2016). A method to measure success dimensions relating to individual stakeholder groups. International Journal of Project Management, 34(3), 480-493. https:// doi.org/10.1016/j.ijproman.2015.12.009

Davis, K. (2017). An empirical investigation into different stakeholder groups perception of project success. International Journal of Project Management, 35(4), 604-617. https://doi. org/10.1016/j.ijproman.2017.02.004

de Oliveira, G. F., \& Rabechini Jr, R. (2019). Stakeholder management influence on trust in a project: A quantitative study. International Journal of Project Management, 37(1), 131-144. https://doi.org/10.1016/j.ijproman.2018.11.001

Derakhshan, R., Turner, R., \& Mancini, M. (2019). Project governance and stakeholders: a literature review. International Journal of Project Management, 37(1), 98-116. https:// doi.org/10.1016/j.ijproman.2018.10.007

De Vita, G., Lagoke, O., \& Adesola, S. (2016). Nigerian oil and gas industry local content development: A stakeholder analysis. Public Policy and Administration, 31(1), 51-79. https://doi.org/10.1177/0952076715581635

Eldanfour, I., Elseraiti, A., \& Abushaiba, I. (2014). The attributes of stakeholders regarding accounting for oil and gas upstream activities in Libya. The Macrotheme Review, 3(6), 58-65.

Erkul, M., Yitmen, I., \& Celik, T. (2019). Dynamics of stakeholder engagement in mega transport infrastructure projects. International Journal of Managing Projects in Business, 13(7), 1465-1495. https://doi.org/10.1108/ IJMPB-09-2018-0175

Eskerod, P., \& Huemann, M. (2013). Sustainable development and project stakeholder management: What standards 
say. International Journal of Managing Projects in Business, 6(1), 36-50. https://doi. org/10.1108/17538371311291017

Eskerod, P., Huemann, M., \& Savage, G. (2015). Project Stakeholder Management - Past and Present. Project Management Journal, 46(6), 6-14. https://doi.org/10.1002/ pmj.21555

Eskerod, P., \& Larsen, T. (2017). Advancing project stakeholder analysis by the concept 'shadow of context'. International Journal of Project Management, 36(1), 161-169. https:// doi.org/10.1016/j.ijproman.2017.05.003

Eyiah-Botwe, E., Aigbavboa, C., \& Thwala, W. D. (2016). Mega Construction Projects: using stakeholder management for enhanced sustainable construction. American Journal of Engineering Research, 5(5), 80-86.

Freeman, R. E. (1984). Strategic Management: A Stakeholder Approach. Boston, MA: Pitman.

Habibi, A., Jahantigh, F. F., \& Sarafrazi, A. (2015). Fuzzy Delphi Technique for Forecasting and Screening Items. Asian Journal of Research in Business Economics and Management, 5(2), 130-143. https://doi.org/10.5958/22497307.2015.00036.5

Hajizadeh, Y. (2019). Machine learning in oil and gas; a SWOT analysis approach. Journal of Petroleum Science and Engineering, 176, 661663. https://doi.org/10.1016/j.petrol.2019.01.113

Ismail, S. A., Heeks, R., Nicholson, B., \& Aman, A. (2018). Analyzing conflict and its management within ICT4D partnerships: an institutional logics perspective. Information Technology for Development, 24(1), 165-187. https://doi.org/10.1080/02681102.2017.1320962

Jones, T. M. (1995). Instrumental stakeholder theory: A synthesis of ethics and economics. Academy of Management Review, 20(2), 404-437. https://doi.org/10.5465/ amr.1995.9507312924

Kaufmann, A., \& Gupta, M. M. (1988). Fuzzy Mathematical Models in Engineering and Management Science. New York, NY: Elsevier Science Publishers.

Kazemi, A., Katebi, A., \& Kazemi, M. H. (2018). Identifying causes of delay in oil and gas construction projects using Fuzzy Delphi method. International Scientific-Practical Magazine, 5, 207-214.

Kerzner, H. R. (2009). Project Management: A Systems Approach to Planning, Scheduling, and Controlling. Hoboken, NJ: Wiley.
Khan, M. I. (2018). Evaluating the strategies of compressed natural gas industry using an integrated SWOT and MCDM approach. Journal of Cleaner Production, 172, 1035-1052. https:// doi.org/10.1016/j.jclepro.2017.10.231

Khatir, M. V., \& Akbarzadeh, Z. (2019). Elucidation of structural relationships of SWOT: A mixed method approach based on FMADM for formulating science and technology strategies. Technology in Society, 56, 44-56. https://doi. org/10.1016/j.techsoc.2018.09.004

Kimiagari, S., Keivanpour, S., Al-Azad, S., \& Mohiuddin, M. (2015). Using the Fuzzy Delphi Method to Apply a Model of Knowledge Transfer through International Strategic Alliances in UpStream Oil and Gas Sectors. Contemporary Management Research, 11(4), 409-428. https://doi.org/10.7903/cmr.13183

Kumaraswamy, M., Wong, K. K. W., \& Chung, J. (2017). Focusing megaproject strategies on sustainable best value of stakeholders. Built Environment Project and Asset Management, 7(4), 441-455. https://doi. org/10.1108/BEPAM-01-2017-0003

Lehtinen, J., \& Aaltonen, K. (2020). Organizing external stakeholder engagement in inter-organizational projects: opening the black box. International Journal of Project Management, 38(2), 85-98. https://doi. org/10.1016/j.jproman.2019.12.001

Li, T. H., Ng, S. T., \& Skitmore, M. (2013). Evaluating stakeholder satisfaction during public participation in major infrastructure and construction projects: A fuzzy approach. Automation in Construction, 29, 123-135. https://doi.org/10.1016/j.autcon.2012.09.007

Li, Y., Lu, Y., \& Peng, Y. (2011). Hierarchical structuring success factors of project stakeholder management in the construction organization. African Journal of Business Management, 5(22), 9705-9713. https://doi. org/10.5897/AJBM.9000317

Locatelli, G., Mancini, M., \& Romano, E. (2014). Systems Engineering to improve the governance in complex project environments. International Journal of Project Management, 32(8), 1395-1410. https://doi.org/10.1016/j. ijproman.2013.10.007

Loosemore, M. (2010). Using multimedia to effectively engage stakeholders in risk management. International Journal of Managing Projects in Business, 3(2), 307-327. https://doi. org/10.1108/17538371011036608 
Mavi, R., Goh, M., \& Zarbakhshnia, N. (2017). Sustainable third-party reverse logistic provider selection with fuzzy SWARA and fuzzy MOORA in plastic industry. The International Journal of Advanced Manufacturing Technology, 91(5-8), 2401-2418. https://doi.org/10.1007/ s00170-016-9880-x

Mbelwa, L. (2018). Investigation of stakeholder management in the oil and gas industry in Tanzania. Business Management Review, 21(1), 34-59. Retrieved from http://hdl. handle.net/20.500.11810/4729

McGrath, S. K., \& Whitty, S. J. (2017). Stakeholder defined. International Journal of Managing Projects in Business, 10(4), 721-748. https://doi.org/10.1108/IJMPB-12-2016-0097

Merrow, E. W. (2012). Oil and gas industry megaprojects: Our recent track record. Oil and Gas Facilities, 1(2), 38-42. https://doi. org/10.2118/153695-PA

Mitchell, R. K., Agle, B. R., \& Wood, D. J. (1997). Toward a Theory of Stakeholder Identification and Salience: Defining the Principle of who and What Really Counts. Academy of Management Review, 22(4), 853-886. https:// doi.org/10.5465/amr.1997.9711022105

Mok, K. Y., Shen, G. Q., \& Yang, J. (2015). Stakeholder management studies in mega construction projects: A review and future directions. International Journal of Project Management, 33(2), 446-457. https://doi. org/10.1016/j.ijproman.2014.08.007

Mok, K. Y., Shen, G. Q., \& Yang, R. J. (2017). Addressing stakeholder complexity and major pitfalls in large cultural building projects. International Journal of Project Management, 35(3), 463-478. https://doi.org/10.1016/j. ijproman.2016.12.009

Mysore, K., Kirytopoulos, K., Ahn, S., \& $\mathrm{Ma}$, T. (2020). Adversarial factors in multistakeholders' engagement of global-IT projects. International Journal of Managing Projects in Business, 14(2), 445-471. https://doi. org/10.1108/IJMPB-01-2019-0014

Nguyen, T. H. D., Chileshe, N., Rameezdeen, R., \& Wood, A. (2019). Stakeholder influence strategies in construction projects. International Journal of Managing Projects in Business, 13(1), 47-65. https://doi. org/10.1108/IJMPB-05-2018-0093

Olander, S., \& Landin, A. (2005). Evaluation of stakeholder influence in the implementation of construction projects. International Journal of Project Management, 23(4), 321-328. https://doi.org/10.1016/j.jproman.2005.02.002
Oppong, G. D., Chan, A. P., \& Dansoh, A. (2017). A review of stakeholder management performance attributes in construction projects. International Journal of Project Management, 35(6), 1037-1051. https://doi.org/10.1016/j. ijproman.2017.04.015

Post, J. E., Lee, E., Preston, L. E., \& Sachs, S. (2002). Redefining the Corporation: Stakeholder Management and Organizational Wealth. Palo Alto, CA: Stanford Business Books.

Pinto, J. K., \& Slevin, D. (1987). Critical factors in successful project implementation. IEEE Transactions on Engineering Management, 34(1), 22-27. https://doi. org/10.1109/TEM.1987.6498856

PMI. (2017). A Guide to the Project Management Body of Knowledge (6th ed.). Newtown Square, PA: Project Management Institute.

Silvério, L., Trabasso, L. T., \& Pessôa, M. V. P. (2019). A roadmap for a leanness company to emerge as a true lean organization. Concurrent Engineering Research and Applications, 28(1), 3-19. https://doi. org/10.1177/1063293X19888259

Tavana, M., Pirdashti, M., Kennedy, D. T., Belaud, J. P., \& Behzadian, M. (2012). A hybrid Delphi-SWOT paradigm for oil and gas pipeline strategic planning in Caspian Sea basin. Energy Policy, 40, 345-360. https://doi.org/10.1016/j. enpol.2011.10.020

Turskis, Z., Zavadskas, E. K., Antucheviciene, J., \& Kosareva, N. (2015). A hybrid model based on fuzzy AHP and fuzzy WASPAS for construction site selection. International Journal of Computers, Communications and Control, 10(6), 113-128. https://doi.org/10.15837/ijccc.2015.6.2078

Tzeng, G. H., \& Teng, J. Y. (1993). Transportation investment project selection with fuzzy multiobjectives. Transportation Planning and Technology, 17(2), 91-112. https://doi. org/10.1080/03081069308717504

Xingang, Z., Jiaoli, K., \& Bei, L. (2013). Focus on the development of shale gas in China - Based on SWOT analysis. Renewable and Sustainable Energy Reviews, 21, 603-613. https://doi.org/10.1016/j.rser.2012.12.044

Yang, J., Shen, G. Q., Drew, D. S., \& Ho, M. (2010). Critical Success Factors for Stakeholder Management: Construction Practitioners' Perspectives. Journal of Construction Engineering and Management, 
136(7), 778-786. https://doi.org/10.1061/ (ASCE)CO.1943-7862.0000180

Yazdi, A. K., Komijan, A. R., Wanke, P. F., \& Sardar, S. (2020). Oil Project Selection in Iran: A Hybrid MADM Approach in an Uncertain Environment. Applied Soft Computing, 88, 106066 . https://doi.org/10.1016/j. asoc.2020.106066

Yu, J., \& Leung, M. Y. (2018). Structural stakeholder model in public engagement for construction development projects. Journal of Construction Engineering and Management, 144(6), 04018046. https://doi.org/10.1061/ (ASCE)CO.1943-7862.0001462

Yu, T., Liang, X., Shen, G. Q., Shi, Q., \& Wang, G. (2019). An optimization model for managing stakeholder conflicts in urban redevelopment projects in China. Journal of Cleaner Production, 212, 537-547. https://doi. org/10.1016/j.jclepro.2018.12.071 